Ekspansi: Jurnal Ekonomi, Keuangan, Perbankan dan Akuntansi

ISSN (Online): 2580-7668 ISSN (Print): 2085-5230

Vol. 11, No. 1 (Mei 2019), Hal. 129 - 139

\title{
DAMPAK KUALITAS LAYANAN DAN NILAI NASABAH TERHADAP KEPUASAN NASABAH PERBANKAN SYARIAH
}

\author{
Hamdani $^{1}$ \\ ${ }^{1}$ Jurusan Tata Niaga, Politeknik Negeri Lhokseumawe, Lhokseumawe, Indonesia \\ Email Korespondensi: hamdani@pnl.ac.id
}

\begin{abstract}
This research refers to studying service quality and customer value towards customer satisfaction in Islamic banking with a case study in PT Bank Syariah Mandiri Lhokseumawe Branch. The data used in this study are primary data through interviews using a questionnaire. The sample in this study was accidental sampling. The research method used is qualitative and quantitative methods, with multiple linear regression analysis. The results released by simultaneous shows, service quality and customer value have a positive and significant influence on customer satisfaction. While the results of the study indicate that, service quality has a positive and significant effect on customer satisfaction, the customer value also has a positive and significant influence on customer satisfaction. From the variable Quality of service and value of customers that are just the same as partial to customer satisfaction in Islamic banking. This research can be used as an evaluation and input for the management of a special sharia banking company, PT Bank Syariah Mandiri, Lhokseumawe Branch, to always improve service quality and value customers receive customers satisfied with services and benefits obtained or obtained by customers.
\end{abstract}

Keywords: Service Quality, Customer Value, Customer Satisfaction

Abstrak: Penelitian ini bertujuan untuk mengetahui pengaruh kualitas layanan dan nilai pelanggan terhadap kepuasan pelanggan pada perbankan syariah dengan studi kasus di PT Bank Syariah Mandiri Cabang Lhokseumawe. Data yang digunakan dalam penelitian ini adalah data primer melalui wawancara dengan menggunakan kuesioner. Sampel dalam penelitian ini adalah accidental sampling. Metode penelitian yang digunakan adalah metode kualitatif dan kuantitatif, dengan analisis regresi linier berganda. Hasil yang diuji secara simultan menunjukkan bahwa, kualitas layanan dan nilai pelanggan memiliki pengaruh positif dan signifikan terhadap kepuasan pelanggan. Sementara hasil penelitian yang diuji secara parsial menunjukkan bahwa, kualitas layanan memiliki pengaruh positif dan signifikan terhadap kepuasan pelanggan, maka nilai pelanggan juga memiliki pengaruh positif dan signifikan terhadap kepuasan pelanggan. Dari variabel Kualitas layanan dan nilai pelanggan yang sama-sama berpengaruh secara parsial terhadap kepuasan pelanggan di perbankan syariah. Penelitian ini dapat digunakan sebagai bahan evaluasi dan masukan untuk manajemen perbankan syariah khususnya PT Bank Syariah Mandiri Cabang Lhokseumawe untuk selalu meningkatkan kualitas layanan dan nilai pelanggan sehingga pelanggan puas dengan layanan dan manfaat yang didapat atau dirasakan pelanggan.

Kata Kunci: Kualitas Layanan, Nilai Pelanggan, Kepuasan Pelanggan

DOI: $10.35313 /$ ekspansi.v11i1.1329

Riwayat Artikel:

Diterima: 8 - 5 - 2019

Direvisi: 24 - 5 - 2019

Disetujui: 26 - 5 - 2019 


\section{PENDAHULUAN}

Kualitas pelayanan terhadap nasabah menjadi salah satu hal yang sangat urgen untuk diperhatikan oleh bank-bank yang beroperasi. Pelayanan yang baik dan paripurna penting untuk memberikan kepuasan kepada nasabah. Pelayanan bank yang baik juga akan memberikan kenyamanan buat nasabah selain itu akan membuat nasabah akan semakin loyal terhadap bank, selain itu akan menambah keparcayaan (trust) kepada bank.

Untuk itu saat ini industri perbankan berlomba-lomba mempromosikan diri dan meningkatkan pelayanan terhadap nasabah, guna mencapai tujuan itu tentu banyak hal yang harus dibenahi oleh industri perbankan, jika tidak maka nasabah akan berpindah ke bank lain. Apalagi saat ini setiap bank selalu menawarkan dan mengiming-imingkan hal -hal yang menggiurkan sesuatu kepada calon nasabah. Hal ini tentu sah-sah saja sebagai bagian dari strategi marketing dari sebuah bank.

Jadi jika pihak perbankan mengharapakan loyalitas dari nasabah, mereka harus mampu dan mau memanjakan konsumen atau nasabahnya. Kalau tidak maka perbankan harus siap-siap ditinggalkan oleh nasabahnya di tengah ketatnya persaingan industri perbankan, tidak terkecuali perbankan syariah yang sudah mulai bergeliat, seiring adanya regulasi di bidang perbankan yang sangat dinamis (Bank Indonesia, 1998).

Tapi ironisnya berdasarkan fenomena sekarang ini ternyata masih banyak bank yang masih mengabaikan pelayanan yang baik kepada nasabah, kondisi ini sudah menjadi rahasia umum terkait pelayanan bank di Indonesia. Kondisi ini banyak diungkapkan nasabah yang mengeluhkan pelayanan bank berdasarkan pengalaman yang dialami, tentang buruknya pelayanan bank, baik itu bank konvensional maupun bank yang berbasis syariah (Marzuki, 2016).

Padahal sejatinya kesuksesan perusahaan termasuk perbankan dalam memberikan pelayanan yang maksimal atau service quality. Adalah seberapa jauh antara harapan dan kenyataan yang diterima oleh pelanggan atau nasabah. Apakah harapan mereka sudah sesuai dengan kenyataan yang diharapakan (Adiwarman Karim dalam Mustagfiroh, 2016).

Selain pelayanan, juga ada nilai nasabah yang harus menjadi prioritas kepuasan nasabah. Sehingga nasabah diharapkan akan merasa puas terhadap pelayanan bank. Nilai nasabah juga tak kalah penting untuk menjadi perhatian perbankan. Nilai nasabah merupakan selisih antara total nilai dan total biaya yang ditimbulkan dari pembelian serta pemakaian barang dan jasa oleh nasabah.

Sementara itu jika dilihat dari lima aspek kualitas pelayanan yang salah satunya yaitu bukti langsung (Tangible), dari segi berpakaian karyawan dalam hal ini adalah PT Bank Syariah Mandiri Cabang Lhokseumawe yang menjadi objek penelitian ini terlihat masih belum sepenuhnya syar'i.

Sedangkan ditinjau dari empat dimensi nilai nasabah salah satunya ialah nilai produk, PT Bank Syariah Mandiri Cabang Lhokseumawe masih belum tersedianya produk pembiayaan khusus untuk petani dan nelayan. Oleh karena itu nilai bagi 
nasabah masih kurang dari segi produk yang disediakan PT Bank Syariah Mandiri Cabang Lhokseumawe sehingga nilai yang diberikan untuk PT Bank Syariah Mandiri Cabang Lhokseumawe diduga masih rendah.

Dilihat dari bukti langsung (Tangible) dan nilai produk, tingkat kepuasan nasabah PT Bank Syariah Mandiri Cabang Lhokseumawe masih belum merasa puas dengan kualitas pelayanan dan nilai nasabah yang di berikan oleh PT Bank Syariah Mandiri Cabang Lhokseumawe kepada nasabahnya.

Melihat fenomena di atas, maka saya tertarik untuk meneliti lebih lanjut tentang dampak kualitas layanan dan nilai nasabah terhadap kepuasan nasabah perbankan syariah. Sengaja saya membatasi penelitian ini, karena mengingat waktu dan biaya. Tetapi sebagai sampel pemilihan objek PT Bank Syariah Mandiri Cabang Lhokseumawe sudah memadai dan tentunya bisa dikembangkan dalam penelitian lanjutan. Khususnya tentang perbankan syariah, demi untuk kemajuan perbankan syariah di Indoensia.

Penelitian ini diharapkan akan bermanfaat untuk pengembangan industri perbankan syariah di Indonesia secara umum. Kemudian dampak terhadap keilmuan adalah bisa menjadi referensi buat peneliti selanjutnya ataupun penelitian-penelitian sejenis, khusunya dalam kaidah keilmuan kontemporer dalam rangka era kebangkitan perbankan syariah di Indonesia dan di negara-negara yang mayoritas berpenduduk muslim di dunia seperti Malaysia dan negara-negara Arab di Timur Tengah.

\section{TINJAUAN PUSTAKA}

\subsection{Kualitas Pelayanan}

Hasil studi menunjukkan bahwa ada beberapa indikator yang menjadi kualitas pelayanan, hal ini seperti yang diungkapkan Parasuraman, dkk (dalam Prastiwi, dkk Yogyakarta, 2017) yang mengatakan bahwa ada sepuluh dimensi pokok kualitas pelayanan, yakni reliabilitas, responsivitas atau daya tanggap, kompetensi, akses, kesopanan, komunikasi, kredibilitas, keamanan, kemampuan memahami pelanggan, bukti fisik, meliputi penampilan fasilitas fisk, peralatan, personel, dan bahan-bahan komunikasi perusahaan (misalnya, kartu bisnis, kop surat, dan lain-lain).

Selanjutnya kualitas pelayanan dapat dimaknai sebagai sejauhmana perbedaan terhadap layanan yang diharapkan oleh nasabah atau pelanggan yang mereka terima, hal ini baru dapat diketahui dengan membandingkan persepsi nasabah terhadap layanan yang mereka peroleh. (Febriana, 2016).

Setidaknya ada lima dimensi pelayanan yang wajib dipenuhi oleh perusahaan dalam melayani pelanggan yang disebut Service Quality (SERVQUAL), yaitu: bukti langsung, kehandalan, daya tanggap, empati, dan jaminan. (Ratmino dan Atik dalam Febriana, 2016).

Dari beberapa pengertian di atas, maka dapat disimpulkan bahwa kualitas pelayanan adalah harapan dan kenyataan menjadi indikator penting terhadap kepuasan nasabah. Nasabah tentu berharap banyak pelayanan yang diberikan akan bisa memenuhi harapan mereka, sehingga mereka akan terpuaskan dan akan semakin loyal. 


\subsection{Nilai Nasabah}

Nilai nasabah merupakan persepsi nasabah terkait dengan keinginan mereka terhadap produk atau jasa yang ditawarkan, menurut Yulandari, dkk (dalam Mustagfiroh, 2016) yang mengatakan bahwa, nilai nasabah adalah persepsi dari apa yang mereka inginkan terjadi, yaitu konsekwensi-konsekwensi dari produk/jasa yang ditawarkan untuk memenuhi kebutuhannya, pada situasi sepesifik (tertentu).

Penilaian nasabah secara menyeluruh terhadap manfaat suatu produk didasarkan apa yang mereka terima dan apa yang telah mereka berikan (Iskawanto Kurniawan, 2015).

Selanjutnya ditambahakan nilai nasabah adalah merupakan sesuatu yang berisfat subjektif. Artinya sesuatu itu buat seorang nasabah mungkin bernilai tapi bisa juga dianggap sebagai beban buat nasabah lainnya, jadi sangat relatif (Iskawanto Kurniawan, 2015).

Oleh sebab itu, dapat dikatakan bahwa perusahaan dalam rangka memenuhi nilai nasabah harus benar-benar membuat strategi yang inovatif dan kreatif supaya dapat dan mampu besaing dengan kompetitor.

Dari pengertian di atas dapat disimpulkan bahwa nilai nasabah merupakan persepsi nasabah, serta harapan-harapan yang diinginkan oleh nasabah untuk terpenuhi. Tentu harapan dari nasabah bersifat relatif. Oleh sebab itu pihak perbankan haruslah peka dalam mensiasatinya.

\subsection{Kepuasan Nasabah}

Kepuasan nasabah menjadi fokus perhatian dari bank-bank yang beroperasi, hal ini karena bank menyadari tentang pentingnya nasabah terhadap kemajuan bisnis mereka. Karena sebuah bank tanpa nasabah tentu akan berdampak terhadap usaha perbankan itu sendiri. Oleh sebab itu, persaingan antar bank sangatlah tinggi dalam memperebutkan calon nasabah baru supaya tertarik menjadi nasabah mereka. Sehingga apapun caranya selama masih layak dilakukan akan mereka perbuat demi pengembangan usaha.

Adapun tentang kepuasan nasabah menurut Tse dan Wilton (dalam Prasetyo, 2012) disebutkan bahwa kepuasan nasabah merupakan respon dari nasabah terhadap evaluasi ketidaksesuaian yang dirasakan setelah pemakaiannya.

Selanjutnya dikatakan bahwa kepuasan nasabah merupakan harapan dari perusahaan terhadap tingkat keunggulan yang diberikan kepada nasabah dan pengendalian atas tingkat keunggulan tersebut untuk memenuhi harapan nasabah (Lovelock dalam Mutaqin, 2006).

Selanjutnya Cahyani (2016) mendefinisikan bahwa faktor-faktor kualitas jasa yang mempunyai andil terbesar sampai terkecil dalam memberikan kepuasan pada nasabah yaitu responsiveness, compliance, emphaty, tangible, reliabity dan assurance. Kemudian kemudahan dalam konsultasi keuangan dan produk syariah menjadi aspek penting dalam memberikan kepuasan pada nasabah di bank syariah. 
Dari beberapa definisi di atas dapat disimpulkan bahwa kepuasan nasabah adalah perbedaan antara yang diharapkan dengan yang diberikan oleh bank terkait dengan kualitas Iayanan, kualitas produk, dan harga. Apabila yang dirasakan nasabah melebihi dugaannya, nasabah akan merasa puas. Sebaliknya apabila kurang dari yang diharapkan maka nasabah tentu akan kecewa.

Untuk itu perbankan harus bekerja keras meyakinkan nasabah bahwa pelayanan yang mereka berikan sudah maksimal dan paripurna. Tentu ini tak mudah, tapi pihak perbankan tak boleh mengurangi pelayanan untuk nasabah mereka, supaya nasabah tetap nyaman.

Hipotesis dalam penelitian ini adalah:

1. Secara Simultan

$\mathrm{HO}_{1}=$ Kualitas Pelayanan dan Nilai nasabah secara simultan tidak berpengaruh positif dan signifikan terhadap Kepuasan Nasabah perbankan syariah.

$\mathrm{Ha}_{1}=$ Kualitas Pelayanan dan Nilai nasabah secara simultan berpengaruh positif dan signifikan terhadap Kepuasan Nasabah perbankan syariah.

2. Secara Parsial

$\mathrm{HO}_{1}=$ Kualitas Pelayanan secara parsial tidak berpengaruh positif dan signifikan terhadap Kepuasan Nasabah perbankan syariah.

$\mathrm{Ha}_{1}=$ Kualitas Pelayanan secara parsial berpengaruh positif dan signifikan terhadap Kepuasan Nasabah perbankan syariah.

$\mathrm{HO}_{1}=$ Nilai nasabah secara parsial tidak berpengaruh positif dan signifikan terhadap Kepuasan Nasabah perbankan syariah.

$\mathrm{Ha}_{1}=$ Nilai nasabah secara parsial berpengaruh positif dan signifikan terhadap Kepuasan Nasabah perbankan syariah.

\section{METODE PENELITIAN}

Dalam penelitian ini mencakup seluruh nasabah di PT Bank Syariah Mandiri Cabang Lhokseumawe. Adapun jumlah seluruh nasabah tersebut dari bulan Januari dan Februari 2018 yaitu sebanyak 393 orang nasabah.

Sedangkan jenis data dalam penelitian ini adalah data primer. Pengumpulan data dilakukan melalui pemberian kuesioner dan wawancara dengan nasabah PT Bank Syariah Mandiri Cabang Lhokseumawe. Poin-poin pertanyaan tersebut sudah tercantum dalam lembaran kuesioner yang telah dipersiapkan.

Teknik pengambilan sampel dalam penelitian ini adalah accidental sampling, yaitu sampel yang dipilih adalah nasabah yang kebetulan ditemui pada saat bertransaksi, penentuan jumlah sampel atau responden dalam penelitian menggunakan pendekatan dengan menggunakan Rumus Slovin, sehingga jumlah sampel ditentukan 80 responden.

Alat analisis yang digunakan dalam penelitian ini adalah regresi linear.

$$
\mathrm{Y}=\boldsymbol{\alpha}+\mathrm{b} 1 \mathrm{X} 1+\mathrm{b} 2 \mathrm{X} 2+\varepsilon
$$


Pengujian hipotesis ini dapat dilakukan dengan uji determinasi $\left(\mathrm{R}^{2}\right)$, uji signifikan simultan (uji F) dan uji signifikan parsial (Uji t).

\section{Uji koefisien Determinasi $\left(\boldsymbol{R}^{2}\right)$}

Koefisien determinasi $\left(\mathrm{R}^{2}\right)$ menunjukkan sejauh mana tingkat hubungan antara variabel dependen (Y) dengan variabel independen. Bila nilai $\mathrm{R}^{2}$ mendekati 0 , berarti sedikit sekali variasi variabel dependen yang diterangkan oleh variabel independen. Jika $\mathrm{R}^{2}$ bergerak mendekati 1 berarti semakin besar variasi variabel dependen yang dapat diterangkan oleh variabel independen,

\section{Uji Simultan dengan F-test}

Uji F dilakukan dengan tujuan untuk mengetahui seberapa jauh semua variabel independen secara bersama-sama dapat mempengaruhi variabel dependen. Jika nilai sig. < 0,05 atau Fhitung < Ftabel, maka HO diterima dan Ha ditolak. Jika nilai sig. > 0,05 atau Fhitung < Ftabel, maka HO ditolak dan Ha diterima.

\section{Uji Parsial dengan T-test}

Uji ini digunakan untuk melihat tingkat signifikansi variabel independen mempengaruhi variabel dependen secara individu atau sendiri-sendiri. Jika t hitung > t tabel, Ha diterima dan Ho ditolak. Jika t hitung $<\mathrm{t}$ tabel, Ho diterima dan Ha ditolak.

Dalam penelitian ini akan menggunakan tiga asumsi klasik yaitu Uji Normalitas, Uji Multikolinearitas, Uji Heteroskedastisitas.

\section{Uji Normalitas}

Bertujuan untuk menguji apakah dalam sebuah model regresi, variabel dipenden, variabel independen, atau keduanya mempunyai distribusi normal atau tidak. Jika data menyebar disekitar garis diagonal dan mengikuti arah garis diagonal, maka model regresi memenuhi normalitas.

\section{Uji Multikolinearitas}

Multikolonieritas dideteksi dengan menggunakan nilai tolerance dan variance inflation factor (VIF). Tolerance $>0,10$ maka model regresi tidak terjadi multikolinearitas dan Tolerance $<0,10$ maka model regresi terjadi multikolinearitas. VIF $<10$ maka model regresi tidak terjadi multikoliniearitas dan VIF $>10$ maka model regresi terjadi multikolinearitas.

\section{Uji Heteroskedastisitas}

Uji heteroskedastisitas bertujuan untuk mengetahui apakah dalam model regresi terjadi ketidaksamaan varian dari suatu residual pengamatan kepengamatan yang lain. Jika titik-titik menyebar di atas dan di bawah angka 0 pada sumbu Y tanpa membentuk pola tertentu maka tidak terjadi heteroskedastisitas. 


\section{HASIL DAN PEMBAHASAN}

Penelitian ini untuk mengetahui apakah kualitas pelayanan dan nilai nasabah berpengaruh terhadap kualitas pelayanan. Hasil dan analisis data dari uji yang sudah dilakukan:

\subsection{Hasil Uji Validitas dan Reliabilitas}

\subsubsection{Uji Validitas}

Uji validitas digunakan untuk mengetahui kelayakan butir-butir dalam suatu daftar pertanyaan dalam mendefinisikan suatu variable. Jika $r$ table $<\mathrm{r}$ hitung maka valid. Pada table 4.16 diatas dapat dilihat dari kolom nilai sig. apabila nilai sig. < 0,05 ini menunjukan bahwa semua item terlihat valid. Dengan begitu seluruh item dalam penelitian ini dapat digunakan.

\subsubsection{Uji Reliabilitas}

Tabel 1. Reliability Statistic

\begin{tabular}{|l|l|l|}
\hline \multicolumn{1}{|c|}{ Variabel } & $\begin{array}{l}\text { Cronbach } \\
\text { Alpha (a) }\end{array}$ & Keterangan \\
\hline $\begin{array}{l}\text { Kualitas Pelayanan } \\
\mathrm{X}_{1}\end{array}$ & 0,891 & Reliabel \\
\hline Nilai Nasabah $\mathrm{X}_{2}$ & 0,897 & Reliabel \\
\hline $\begin{array}{l}\text { Kepuasan } \\
\text { Nasabah Y }\end{array}$ & 0,730 & Reliabel \\
\hline
\end{tabular}

Sumber: Data kuesioner yang telah diolah (2018)

Hasil dari table Reliability Statistics bahwa masing-masing variable memiliki nilai Cronbach Alpha (a) lebih besar dari 0,60 sehingga data tersebut dapat dikatakan reliable atau memenuhi syarat.

\subsection{Uji Asumsi Klasik}

\subsubsection{Uji Normalitas}

Uji Normalitas bertujuan untuk menguji apakah dalam sebuah model regresi, variable dependen, variable independen, atau keduanya mempunyai distribusi normal atau tidak.

Gambar 1. Normalitas Data

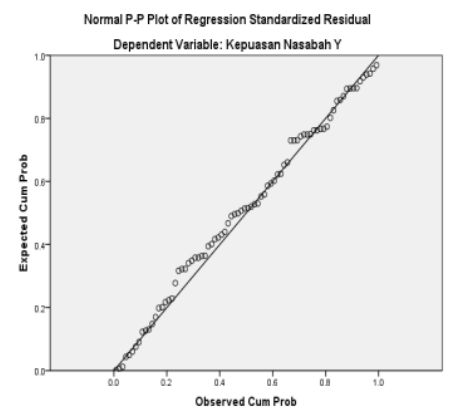

Sumber: Data kuesioner yang telah diolah (2018) 
Data tersebut menunjukan bahwa garis diagonal berdistribusi normal yaitu dilihat pada titik-titik data yang menyebar disekitar garis diagonal dan mengikuti garis diagonal.

\subsubsection{Uji Multikolinearitas}

Uji multikolonieritas bertujuan untuk menguji apakah dalam model regresi ditemukan adanya korelasi antar variabel bebas.

Tabel 2. Hasil Uji Multikoliniearitas

\begin{tabular}{|ll|l|l|}
\hline \multirow{2}{*}{ Model } & \multicolumn{2}{|l|}{ Collinearity Statistics } \\
\cline { 3 - 4 } & (Constant) & Tolerance & VIF \\
\hline \multirow{2}{*}{1} & Kualitas Pelayanan X1 & .408 & \\
& Nilai Nasabah X2 & .408 & 2.454 \\
\end{tabular}

Sumber: Data kuesioner yang telah diolah (2018)

Kolom tolerance yang hasil pengujian nilainya di atas 0,10 yaitu kualitas pelayanan X1 $(0,408)$ dan nilai nasabah X2 $(0,408)$. Demikian pula pada kolom VIF yang hasil pengujian nilainya kurang dari 10 yaitu kualitas pelayanan X1 $(2,454)$ dan nilai nasabah X2 $(2,454)$. Model regresi tidak terjadi multikolinearitas.

\subsubsection{Uji Heteroskedastisitas}

Uji heteroskedastisitas bertujuan untuk mengetahui apakah dalam model regresi terjadi ketidaksamaan varian dari suatu residual pengamatan kepengamatan yang lain.

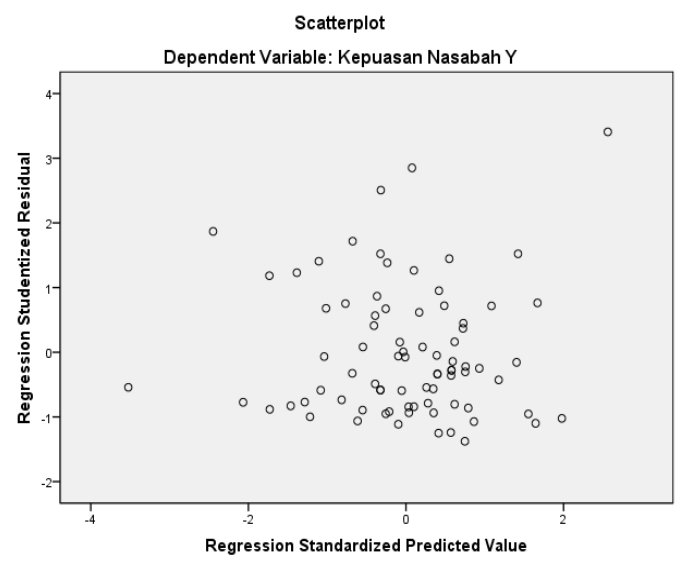

Gambar 2. Hasil Uji Heteroskedastisitas Glejser

Sumber : Data kuesioner yang telah diolah (2018)

Terlihat bahwa titik-titik dari data yang dimasukan menyebar di atas dan di bawah angka 0 pada sumbu Y dan tidak menyempit, tidak berbentuk pola tertentu serta tidak berbentuk gelombang. Hasil tersebut berarti tidak terjadi heteroskedastisitas. 


\subsection{Uji Hipotesis}

\subsubsection{Uji Koefisien Determinasi $\left(\mathrm{R}^{2}\right)$}

Berdasarkan hasil uji koefisien korelasi menunjukan sejauh mana tingkat hubungan antara variabel dependen dengan variabel independen.

Tabel 3. Hasil Koefisien Determinasi $\left(R^{2}\right)$

\begin{tabular}{|r|c|c|c|}
\hline Model & R & R Square & Adjusted R Square \\
\hline 1 & 0,643 & 0,414 & 0,399 \\
\hline
\end{tabular}

Terlihat bahwa nilai $\mathrm{R}$ atau korelasi berganda sebesar 0,643 atau $64,3 \%$ yang artinya variabel independen mempunyai hubungan yang kuat terhadap variabel dependen. Koefisien $R$ Square sebesar 0,414 atau 41,4\%, hal tersebut menggambarkan bahwa pengaruh kualitas pelayanan dan nilai nasabah terhadap kepuasan nasabah. Hal ini sesuai dengan teori yang telah dikemukan sebelumnya.

\subsubsection{Uji Simultan dengan F-test}

Uji F dilakukan dengan tujuan untuk mengetahui seberapa jauh semua variabel independen secara bersama-sama dapat mempengaruhi variabel dependen.

Tabel 4. Hasil Uji Simultan dengan F-test

\begin{tabular}{|ll|l|l|}
\hline \multicolumn{2}{|c|}{ Model } & F & Sig. \\
\hline 1 & $\begin{array}{l}\text { Regression } \\
\text { Residual } \\
\text { Total }\end{array}$ & 27.200 & $.000^{\mathrm{a}}$ \\
& & \\
\hline
\end{tabular}

Sumber : Data kuesioner yang telah diolah (2018)

$F_{\text {hitung }}$ sebesar 27,200 jauh lebih besar dari $\mathrm{F}_{\text {tabel }}$ sebesar 3,11 yang di peroleh dari $\mathrm{F}_{\text {tabel. }}$ maka $\mathrm{H}_{0}$ ditolak dan menerima $\mathrm{H}_{\mathrm{a}}$

\subsubsection{Uji Parsial dengan T-test}

Uji ini digunakan untuk melihat tingkat signifikansi variabel independen mempengaruhi variabel dependen secara individu atau sendiri-sendiri.

Adapun hasil uji parsial dengan T-Test seperti yang terlihat dalam tabel 5 berikut ini:

Table 5. Hasil Uji Parsial dengan T-test

\begin{tabular}{|cl|c|c|}
\hline \multicolumn{1}{|c|}{ Model } & T & Sig. \\
\hline \multirow{4}{*}{1} & (Constant) & 1.772 & .080 \\
& Kualitas Pelayanan X1 & 2.232 & .029 \\
& Nilai Nasabah X2 & 2.770 & .007 \\
\hline
\end{tabular}

Sumber: Data kuesioner yang telah diolah (2018) 
1. Diketahui nilai signifikan thitung Kualitas Pelayanan (X1) sebesar 2,232 lebih besar dari tabel yaitu sebesar 1,991 dan nilai sig. 0,029 lebih kecil dari a 0,05 sehingga $\mathrm{H}_{0}$ ditolak dan $\mathrm{H}_{\mathrm{a}}$ diterima.

2. nilai signifikan $t_{\text {hitung }}$ Nilai Nasabah (X2) sebesar 2,770 lebih besar dari tabel yaitu sebesar 1,991 dan nilai sig. 0,007 lebih kecil dari a 0,05 sehingga $\mathrm{H}_{0}$ ditolak dan $\mathrm{H}_{\mathrm{a}}$ diterima.

\subsection{Analisis Data}

Untuk dapat mengetahui pengaruh antara variable X1 kualitas pelayanan dan variable $\mathrm{X}_{2}$ nilai nasabah terhadap variable $\mathrm{Y}$ kepuasan nasabah.

Tabel 6. Hasil Uji Analisis Data

\begin{tabular}{|c|l|c|c|}
\hline \multicolumn{2}{|c|}{ Model } & \multicolumn{2}{c|}{ Unstandardized Coefficients } \\
\cline { 3 - 4 } \multicolumn{2}{|c|}{1} & B & Std. Error \\
\hline \multirow{3}{*}{1} & (Constant) & 4.442 & 2.507 \\
\cline { 2 - 4 } & Kualitas Pelayanan X1 & .088 & .039 \\
\cline { 2 - 4 } & Nilai Nasabah X2 & .119 & .043 \\
\hline
\end{tabular}

Sumber: Data kuesioner yang telah diolah (2018)

$$
\mathrm{Y}=4,442+0,088 \mathrm{X} 1+0,119 \mathrm{X} 2
$$

a. Nilai konstanta model persamaan regresi adalah sebesar 4,442.

b. Nilai koefisien regresi kualitas pelayanan adalah sebesar 0,088. setiap peningkatan sebesar 1 kali maka kepuasan nasabah akan meningkat 8,8\%.

c. Nilai koefisien regresi nilai nasabah adalah sebesar 0,119 . setiap peningkatan sebesar 1 kali maka kepuasan nasabah akan meningkat 11,9\%.

\section{PENUTUP}

Berdasarkan Penelitian dan pembahasan yang telah diuraikan sebelumya maka dapat ditarik beberapa kesimpulan bahwa kualitas pelayanan dan nilai nasabah merupakan hal yang paling dominan mempengaruhi kepuasan nasabah perbankan syariah. Oleh sebab itu, jika ingin terus berkembang dan tetap eksis, maka perbankan syariah harus lebih proaktif dalam memberikan dan memperbaiki kualitas pelayanan terhadap nasabah. Demikian juga dengan nilai nasabah perlu lebih ditingkatkan. Sehingga nasabah akan loyal.

\section{DAFTAR PUSTAKA}

Bank Indonesia. (1998). Undang-Undang Nomor 10 Tahun 1998 Tentang Perbankan.

$$
\begin{aligned}
& \text { UNDANG-UNDANG NOMOR } 10 \quad \text { TAHUN } 1998 . \\
& \text { https://doi.org/10.1007/s13398-014-0173-7.2 }
\end{aligned}
$$

Cahyani, P. D. (2016). TINGKAT KEPUASAN NASABAH TERHADAP KUALITAS LAYANAN PERBANKAN SYARIAH DI YOGYAKARTA. Esensi: Jurnal Bisnis 
Dan Manajemen, 6(September), 151-162. https://doi.org/10.15408/ess.v6i2.3570

Febriana, N. I. (2016). ANALISIS KUALITAS PELAYANAN BANK TERHADAP KEPUASAN NASABAH PADA BANK MUAMALAT INDONESIA KANTOR CABANG PEMBANTU TULUNGAGUNG. AN-NISBAH, 3(1).

Iskawanto Kurniawan, M. S. S. (2015). PENGARUH NILAI NASABAH, KUALITAS PELAYANAN, DAN KUALITAS HUBUNGAN TERHADAP KEPUASAN NASABAH SERTA IMPLIKASINYA TERHADAP LOYALITAS NASABAH BANK SYARIAH MANDIRI. Manajemen Dan Bisnis Sriwijaya, 13(2).

Marzuki, A. (2016). Kualitas Pelayanan Bank yang Kurang Baik.

Mustagfiroh, F. (2016). Penangan Keluhan, Nilai Nasabah terhadap Kepuasan Nasabah dan Word of Mouth. UNIVERSITAS ISLAM NEGERI WALISONGO SEMARANG. Mutaqin, A. (2006). ANALISIS PENGARUH KUALITAS PELAYANAN DAN FASILITAS TERHADAP KEPUASAN PELANGGAN BUS PO . TIMBUL JAYA di WONOGIRI.

Prasetyo, A. (2012). ANALISIS FAKTOR-FAKTOR YANG MEMPENGARUHI KEPUASAN NASABAH DAN PENGARUHNYA TERHADAP LOYALITAS NASABAH PADA PT. BPR RUDO INDOBANK SEMARANG. JURNAL SAINS PEMASARAN INDONESIA, XI(1), 20-36.

Prastiwi, R. D. (2017). Pengaruh Dimensi Kualitas Pelayanan terhadap Kepuasan Nasabah. 